\title{
Pendidikan Pemilih sebagai Metode Meningkatkan \\ Partisipasi dan Keterampilan Pemilih Pemula Menggunakan Hak Pilihnya dalam Pemilu
}

\section{Zakaria Ansori}

Fakultas Ushuluddin dan Studi Agama, UIN Mataram

Email:zakariaansori@uinmataram.ac.id

\begin{abstract}
Abstrak: Artikel ini diolah dari hasil pelaksanaan pengabdian kepada masyarakat. Pokok bahasannya tentang pendidikan pemilih terhadap pemilih pemula. Dilatarbelakangi oleh fenomena beberapa negara demokrasi dalam tahun-tahun terakhir yang menunjukkan semakin menurunnya partisipasi pemilih. Dalam usaha merespon fenomena tersebut, pengabdian ini memiliki dua tujuan. Pertama, meningkatkan pengetahuan siswa/siswi tentang kepemiluan dalam sistem demokrasi di Indonesia. Kedua, meningkatkan keterampilan siswa/siswi dalam menggunakan hak pilihnya pada pemilu. Muatan materi yang diberikan ada tiga aspek, yakni; (1) pemilu dan demokrasi; (2) sistem pemilu; (3) praktik pemilu di Indonesia. Hasil pengabdian memperlihatkan adanya perubahan pemahaman siswa/siswi tentang pemilu sekaligus perubahan sikap mereka terhadap isu golput.
\end{abstract}

Kata Kunci: Pendidikan Pemilih, Partisipasi Politik, Keterampilan Pemilih, Pemilu

\begin{abstract}
This paper, a report from a community service project, mainly discusses the notion of voting education for beginner voters amid increasingly low participation of voters' participation in some democratic states. For this reason, the project reported in this paper has two primary purposes: first, help students' develop the knowledge of election within the Indonesian political sphere; second, encourage the students to use their rights in the election. There were three designed materials employed: (1) election and democracy; (2) election system; (3) election practice in Indonesia. The findings showed that the project training could change the st $u-$ dents' attitude pertinent to the election and encourage them not to abstain in the election.
\end{abstract}

Keywords: Voting education, political participation, voters' competence, general election 


\section{Pendahuluan}

Memberikan suara dalam pemilu, merupakan bentuk partisipasi politik konvensional individu paling minimal sebagai warga negara. ${ }^{1}$ Oleh karena itu, fenomena menurunnya angka partisipasi masyarakat dalam ikut memilih menjadi kehawatiran banyak negara demokrasi era ini. Secara terminologis, ketidakhadiran masyarakat dalam pemberian suara pada pemilu dikonsepsikan sebagai golongan putih (golput). Perkatan lainnya, golput merupakan konsep yang digunakan untuk menjelaskan sikap masyarakat ketika tidak menggunakan hak pilihnya dalam pemilu atau tidak hadir memilih.

Beberapa negara menunjukkan angka golput pemilunya berada pada kondisi memprihatinkan. Di kawasan Asia, misalnya Thailand menjadi negara paling tinggi angka golput-nya. Pada pemilu bulan Februari tahun 2014, warga negara Thailand yang berpartisipasi dalam pemungutan suara hanya $46,79 \%$, artinya angka golput mencapai 53,21\%. Di kawasan Eropa Timur, negara Lithuania yang memiliki populasi 2,9 juta, pada, pemilu tahun 2012, angka partisipasi pemilih hanya 35,91\%, maka artinya golput mereka mencapai 64,09\%.

Sementara itu, di kawasan Amerika Utara, negara Haiti dari 3,5 juta rakyat yang terdaftar dalam daftar pemilih, hanya $28,31 \%$ yang berpartisipasi menggunakan hak pilihnya pada pemilu 2006. Maka artinya angka golput mencapai 71,69 \%. Di kawasan Benua Afrika, Nigeria pada pemilu 2011, dari 73,5 juta penduduk terdaftar, hanya $28,9 \%$ yang menyalurkan suaranya. Ini artinya angka golput men-

${ }^{1}$ Budi Suryadi, Sosiologi Politik; Sejarah, Definisi, dan Perkembangan Konsep (Jogjakarta, IRCiSoD, 2007), hlm.133. Suryadi meminjam penjelasan Almond (1993) dalam menerangkan dua macam partisipasi politik, yaitu kegiatan politik konvensional dan non-konvensional. Kegiatan politik konvensional adalah bentuk partisipasi politik yang normal dalam demokrasi modern. Bentuk partisipasi politik konvensional adalah; pemberian suara (voting), diskusi politik, kegiatan kampanye, membentuk dan bergabung dalam kelompok kepentingan, komunikasi individu dengan pejabat politik dan administrasi. Bentuk partisipasi politik non-konvensional adalah yang tidak normal, meskipun demikian bisa legal (seperti petisi) maupun yang illegal seperti kekerasan dan revolusioner. Di antara bentuk-bentuknya adalah mogok, berdemonstrasi, mogok, tindak kekerasan politik 
capai $71,1 \%$. Pada pemilu 2012, di negara ini hanya 19,44\% rakyat mencoblos dari 796,9 ribu pemilih terdaftar. Artinya angka golput mencapai $80,56 \% .^{2}$

Statistik pemilu di atas menunjukkan rendahnya partisipasi memilih masyarakat atau tingginya angka golput di banyak negara sudah berada pada posisi yang menghawatirkan secara politik. Pada negara-negara di atas, rata-rata angka golput sudah berada di atas angka partisipasi pemilih. Artinya warga negara yang tidak menggunakan hak pilih lebih tinggi dibandingkan yang menggunakan hak pilih. Fenomena ini sekaligus menandakan tumbuhnya gejala a-politik masyarakat. Bagi kelompok masyarakat apolitik, mereka memandang politik bukan lagi urusannya. Politik dipandang tidak memberikan impact langsung bagi masyarakat, politik tidak memberikan pengaruh ekonomi bagi masyarakat. Dan karena itu, politik hanyalah merupakan urusan elit.

Di Indonesia angka golput masih dalam posisi yang proporsional. Pada pemilu anggota DPR dan DPD tahun 2014, misalnya dari 187.852.992 warga negara terdaftar dalam daftar pemilih, yang menggunakan hak pilihnya $75,55 \%$, atau angka golput mencapai $24,45 \% .^{3}$ Data ini memperlihatkan secara nasional angka partisipasi pemilih Indonesia masih lebih tinggi apabila dibandingkan beberapa negara lain.

Lombok Tengah sebagai kabupaten tempat pengabdian ini dilaksanakan, angka partisipasi pemilih di setiap kecamatan memiliki keberagaman. Dari 12 kecamatan yang ada, angka partisipassi pemilih Lombok Tengah cukup beragam. Kecamatan Pujut merupakan daerah paling tinggi angka partisipasi pemilihnya, disusul Praya Timur, Praya, Praya Barat, Praya Tengah, Praya Barat Daya, Janapria, Batu Kliang, Batu Kliang Utara, Jonggat, Pringgarata, dan Kopang.

Praya merupakan Ibu Kota Kabupaten Lombok Tengah yang memiliki keberagaman atau pluralitas. Praya dihuni penduduk dari

${ }^{2}$ http://kumpulan-berita-unik.blogspot.co.id/2014, dikutp tanggal 25 Februari 2017

${ }^{3}$ Komisi Pemilihan Umum, Buku Data dan Infografik Pemilu Anggota DPR RI dan DPD RI Tahun 2014, hlm 278 
semua agama dan beragam suku bangsa. Sebagai Ibu Kota dengan pusat perdagangan, pemerintahan, dan pendidian di Lombok Tengah, Praya merupakan pertemuan penduduk Lombok Tengah dari semua kecamatan yang ada. Oleh karena itu, Praya merupakan representasi dari masyarakat Lombok Tengah. Berdasarkan kondisi tersebut, pengabdian ini mengambil lokasi di Kota Praya, persisnya di Pondok Pesantren Darul Muhajirin-Praya. Fokus pengabdian ini pada dua poin. Pertama, pemahaman siswa/siswi MA Darul Muhajirin sebagai pemilih pemula tentang pemilu dan pandangan mereka tentang golput sebelum pemberian materi kepemiluan oleh narasumber. Kedua, pemahaman siswa/siswi MA Darul Muhajirin sebagai pemilih pemula tentang pemilu dan pandangan mereka tentang golput sebelum pemberian materi kepemiluan. Lokasi pengabdian di MA Darul Muhajirin Praya. MA ini terletak di Kota Praya sebagai Ibu Kota Kabupaten Lombok Tengah.

\section{Pembahasan}

\section{Sosialisasi Politik Sebagai Pendidikan Politik}

Cara paling sederhana mendefinisikan sosialisasi politik adalah dengan menggabungkan makna sosialisasi dan politik. Meskipun demikian, penggabungan ini tidak sederhana karena definisi politik yang dikemukakan para ahli masih beragam. Damsar mendefinisikan sosialisasi politik sebagai proses trenaformasi pengetahuan, sikap, dan nilai politik kepada masyarakat agar masyarakat mampu berpartisipasi politik secara efektif. ${ }^{4}$ Kesimpulan ini merupakan perpaduan dari pendapat beberapa ahli, sebagai berikut:

1. M.Rush dan P.Althoff, dalam bukunya yang diberi judul Sosiologi Politik, tahun 2005, mereka mengatakan sosialisasi politik adalah suatu proses kerja terhadap dua hal. Pertama, memperkenalkan sistem politik kepada peserta sosialisasi politik. Kedua, meminta respon atau tanggapan mereka tentang gejala-gejala politik.

${ }_{4}^{4}$ Prof.Dr.Damsar, PengantarSosiologi Politik, Edisi Revisi(Jakarta, Kencana Prenada Media Group, 2013), hlm.154 
2. A.Thio, dalam bukunya Sociology: An Introduction, tahun 1989, Thio mengatakan, sosialisasi politik sebagai proses melalui mana individu memperoleh pengetahuan, kepercayaan, dan sikap politik.

3. Gabriel A.Almond, mengatakan sosialisasi politik adalah bagian dari proses sosialisasi yang secara khusus membentuk nilai-nilai politik, yang menunjukkan bagaimana seharusnya seseorang berpartisipasi dalam kehidupan politik. ${ }^{5}$

Paparan definisi sosialisasi politik di atas mempertegas, kerja sosialisasi politik pada dua aspek, yaitu ; aspek yang berhubungan dengan proses dan aspek yang berhubungan dengan tujuan. Pada aspek pertama, kerja sosialisasi politik merupakan transformasi nilainilai, pengetahuan, kepercayaan, dan sikap politik, serta harapan politik. Adapun aspek kedua, merujuk pada sesuatu yang diperlukan oleh individu agar mampu berpartisipasi efektif dalam aspek politik dan kehidupan masyarakat.

\section{Agen Sosialisasi Politik}

Agen sosialisasi politik dapat dilakukan oleh berbagai aktor, baik individu, kelompok atau organisasi. Damsar membuat identifikasi terhadap empat agen sosialisasi strategis, yakni; keluarga, sekolah, kelompok teman sebaya, dan media massa. Menurut Damsar, agen-agen ini paling penting perannya dalam membentuk pengetahuan, sikap, nilai, norma dan perilaku esensi manusia. ${ }^{6}$ Apa yang dirumuskan oleh Damsar tidak lebih sebagai salah satu panduan bagi setiap ahli untuk merumuskan identifikasi agen-agen lainnya. Penulis berpandangan ada banyak agen lain yang dapat mengambil peran dalam sosialisasi politik, seperti elit informal (kyai, buya, atau tuan guru, termasuk tokoh-tokoh budaya), organisasi-organisasi masyarakat (ormas), dan lembaga swadaya masyarakat.

a. Keluarga

Di dalam keluarga, sosialisasi politik dapat berjalan melalui dua bentuk, yaitu sosialisasi represif dan sosialisasi partisipatif. Ben-

\footnotetext{
5 Ibid, hlm.153

${ }^{6}$ Ibid, hlm.154
} 
tuk sosialisasi politik ini sangat ditentukan oleh karekteristik orang tua, karena orang tua merupakan aktor dominan dalam pembentukan peran anggota keluarga. Pada tahapan yang ekstrim bahkan muncul asumsi, "watak dan prilaku anak merupakan potret dari watak dan perilaku orang tua". Damsar mendefinisikan sosialisasi represif sebagai sosialisasi yang lebih menekankan pada kepatuhan anak dan pemberian hukuman terhadap perilaku yang keliru. Misalnya, orang tua yang mengharuskan anak untuk taat terhadap apapun perintah orang tua, atau anak di larang makan sebelum orang tua makan, melarang anak ikut berdiskusi ketika orang tua sedang mendiskusian suatu hal, dan memberikan hukuman bagi anak yang melanggar nilai atau norma sosial. Sedangkan sosialisasi partisipatif, menunjuk pada sosialisasi yang menekankan pada otonomi anak, dan biasanya memberikan imbalan pada anak yang baik. Apabila pada pola sosialisasi represif, anak mendapatkan tekanan yang begitu hebat hingga tidak diperbolehkan nimbrung dalam diskusi orang tua, maka pada pola sosialisasi partisipatif, berlaku pakem yang sebaliknya, orang tua cenderung melibatkan anaknya dalam mendiskusikan hampir semua rencana-rencana yang akan dilakukan.

Pola sosialisasi anak yang diperoleh melalui keluarga diyakni para ilmuan sosial akan memberi impack pada sikap dan perilaku politik anak ketika menjadi dewasa. Ketika politisi yang waktu anakanak mendapatkan sosialisasi politik represif, kecenderungannya akan tumbuh menjadi politisi yang diktator. Sebaliknya, karekter politik demokratis seorang politisi, biasanya muncul karena pola sosialisasi politik di keluarga yang partisipatif. Damsar mencoba membuat rumusan bentuk sosialisasi politik yang berbeda ini, sebagaimana tabel berikut.

Tabel.1. Bentuk Sosialisasi Politik

\begin{tabular}{ll}
\hline \multicolumn{1}{c}{ Sosialisasi Represif } & \multicolumn{1}{c}{ Sosialisasi Partisipatif } \\
\hline - Menghukum perilaku yang keliru & - Memberi imbalan bagi perilaku \\
- Hukuman dan imbalan material & \multicolumn{1}{c}{ yang baik } \\
- Kepatuhan anak & - Hukuman dan imbalan simbolis \\
- Komunikasi sebagai perintah & - Otonomi anak \\
- Komunikasi nonverbal & - Komunikasi sebagai interaksi \\
- Sosialisasi yang berpusat pada & - Komunikasi verbal \\
$\quad$ orang tua & - Sosialisasi yang berpusat pada anak \\
\hline
\end{tabular}




\begin{tabular}{lll}
\hline \multicolumn{1}{c}{ Sosialisasi Represif } & \multicolumn{2}{c}{ Sosialisasi Partisipatif } \\
\hline - Anak memperhatikan keinginan & - Orang tua memperhatikan \\
orang tua & $\begin{array}{l}\text { keperluan anak } \\
\text { - Keluarga merupakan significant } \\
\text { other }\end{array}$ & $\begin{array}{l}\text { - Keluarga merupakan generalized } \\
\text { other }\end{array}$ \\
\hline
\end{tabular}

Sumber : Damsar, hlm.155

Pada masyarakat pedesaan sebelum tahun 1990-an, hampir semua orang tua menerapkan pola sosialisasi represif pada anak. Kebetulan penulis tinggal dan besar dilingkungan pedesaan dan $\mathrm{m}$ asa kecil penulis dalam keluarga banyak kekurangan secara ekonomi, sebagaimana juga jamak terjadi pada masyarakat pedesaan saat itu. Ikan tongkol (sejenis ikan laut) waktu itu merupakan makanan yang mewah, dan setiap makanan mewah, maka yang didahulukan adalah orang tua. Jadi ada tuntutan bagi setiap anak dipedesaan untuk memperhatikan keinginan orang tua sebagai bentuk kepatuhan dan penghormatan anak terhadap orang tua.

Penulis berpandangan, fenomena pola sosialisasi represif dalam keluaraga menyebabkan hampir semua pemimpin politik saat itu tampil dengan pola-pola diktator, mulai dari kepala desa hingga presiden. Maka perilaku politik masyarakat juga cenderung mengamini pemimpin-pemimpin yang dipandang kuat secara fisik. Disitulah area subur bagi legitimasi politik militer dan birokrasi, sehingga karekteristik politik di sekitar tahun 1990-an, menurut penulis adalah politik teknokratik, yaitu sistem politik yang dikuasi militer dan birokrasi. Kekuasaan presiden Soeharto, misalnya ketika itu di topang oleh mesin politik A, B, G (ABRI, Birokrasi, dan Golkar). M esin politik ini bekerja dari pemerintah pusat hingga pemerintah desa. Warga masyarakat kemudian di tutntut kepatuhannya terhadap penguasa, dan menyebabkan Soeharto mampu berkuasa 32 tahun, sebagai presiden paling lama dalam sejarah politik Indonesia.

\section{b. Sekolah}

Pertanyaannya, mengapa sekolah menjadi agen penting sosialisasi politik? Sedikitnya ada dua faktor yang dapat diidentifikasi sebagai penyebabnya, yaitu karena sekolah sebagai sistem sosial dan karena di sekolah guru merupakan figur sentral bagi siswa. Yang 
dimaksud dengan sekolah sebagai sistem sosial adalah, sekolah merupakan wadah di mana didalamnya ada sejumlah kegiatan atau sejumlah orang yang hubungan timbal baliknya kurang lebih bersifat konstan. Di sekolah hubungan sosial antara siswa dengan siswa, siswa dengan guru, guru dengan guru, dan guru dengan Kepala Sekolah, semuanya bersifat konstan atau relatif permanen. Sifat konstanitas hubungan sosial di sekolah memberi ruang yang efektif untuk proses sosialisasi politik.

Guru, merupakan agen sosialisasi yang penting untuk proses sosialisasi politik. Sudah barang tentu karena guru merupakan figur yang tidak hanya berfungsi sebagai transformasi nilai-nilai dan transformasi ilmu pengetahuan. Lebih dari itu, guru menjadi model bagi tindak-tanduk, cara berpikir, dan sikap siswa. Penampilan (performance) guru, menjadi rujukan utama siswa. Oleh karena itu, ucapan, nasehat dan perintah guru menjadi "fatwa" yang wajib ditaati oleh siswa. Dalam posisi sosial yang demikian, guru menjadi penyampai pesan sosialisasi strategis di sekolah.

Gaya kepemimpinan guru, merupakan faktor dominan yang mempengaruhi produktivitas siswa di ruang kelas. Damsar membagi tiga jenis gaya kepemimpinan guru yang kemudian dapat mempengaruhi proses sosialisasi politik melalui agen sekolah, yaitu; otokratik, demokratik, dan laisser-fair. ${ }^{7}$ Gaya kepemimpinan guru yang relevan dengan sosialisasi politik adalah gaya kepem impinan demokratik. Gaya kepemimpin demokratik diyakini mampu membangun sikap kriis sekaligus konstruktif bagi siswa. Oleh karena itu, gaya kepemimpinan demokratik merupakan solusi pendidikan sepanjang zaman. Dengan demikian, apabila sekolah masih dipandang efektif sebagai agen sosialisasi politik, maka kompetensi guru tentang kepolitikan menjadi kebutuhan untuk dihadirkan.

\section{c. Kelompok teman sebaya}

Dalam tradisi sosiologi, kelompok teman sebaya (peer group), didefinisikan sebagai suatu kelompok dari orang-orang yang seusia dan memiliki status yang sama, dengan siapa seseorang itu bergaul

${ }^{7}$ Ibid, hlm.162 
atau berhubungan. Biasanya kelompok teman sebaya merupakan k elompok rujukan (reference group) dalam mengembangkan sikap dan perilaku yang berhubungan dengan politik.

Sosialisasi poltiik melalui kelompok teman sebaya dapat dilakukan dengan berbagai cara. Tetapi cara yang dipandang efektif melaksanakan sosialisasi di kelompok temaan sebaya adalah dengan sosialisasi informal dan tatap muka langsung. Sosialisasi politik melalui teman sebaya banyak dilakukan oleh lembaga-lemaba publik. Salah satu lembaga publik yang memiliki program sosialisasi politik melalui teman sebaya adalah Komisi Pemilihan Umum (KPU). Jumlah pemilih yang tinggi dibandingkan jumlah pegawai KPU yang terbatas, menjadi salah satu motivasi KPU membentuk komunitas pemilu dan demokrasi. KPU membuat pengelompokan segmentasi pemilih, salah satu segmen yang paling cepat pertumbuhannya adalah pemilih pemula. Untuk menjangkau pemilih pemula dalam sosialisasi pemilu, KPU melakukan rekrutmen terhadap pelajar dan mahasiswa. Kedua kelompok pemilih ini diberikan kurusus pemilu dan selanjutnya mereka diberi tugas untuk melaksanakan sosialisasi pemilu pada kelompok teman sebaya mereka, misalnya teman-teman mereka yang ada di dalam sekolah atau kampus. Fenomena ini menunjukkan peran penting dari kelompok teman sebaya sebagai agen sosialisasi politik.

\section{d. Media massa}

Pada masyarakat komunikasi seperti era ini, media massa memiliki peran paling strategis sebagai agen sosialisasi politik. Media massa di era ini telah berfungsi mempengaruhi cara pandang, cara berpkir, cara bertindak, dan sikap politik seseorang. Pengaruh media massa saat ini bersifat massif, berskala besar, bahkan segera. Misalnya, apa yang terjadi di negara lain dapat kita ketahui dalam hitungan menit melalui media sosial. Oleh karena peran media yang begitu penting, semua partai politik berusaha menggunakan sebanyak-banyaknya media massa sebagai agen sosialisasi poltiik. Media massa di zaman ini telah menjadi satu-satunya agen yang dapat mempengaruhi masyarakat, misalnya terhadap kandidat tertentu. Tengoklah peristiwa pemilukada DKI yang baru lalu. Pada 
pemilukada DKI 2017 yang berkontestasi ketika itu, bukan hanya para kandidat, bahkan juga ada pertarungan media massa. ,Media massa dapat menyediakan citra baik sekaligus citra buruk bagi politisi yang sedang berkontestasi. Oleh karena itu, setiap momentum pem ilu di Indonesia, media massa harus digandeng oleh partai politik bersama politisinya.

Pemilahan agen-agen sosialisasi politik yang dibuat oleh Damsar memilik kemiripan dengan pemilahan yang dilakukan oleh Elly M.Setiadi dan Usman Kolip. Mereka membagi dua kelompok agen sosialisasi, yaitu secondary group dan primary group. Kelompok pertama terdiri dari pemerintah, sekolah, media massa, dan partai politik. Sedangkan kelompok kedua terdiri dari teman sebaya (peer groups) dan keluarga. ${ }^{8}$

Agen yang baru dari Setiadi dan Kollip adalah peran partai politiik sebagai agen sosialisasi politik. Peran partai politik sebagai agen sosialisasi politik memang kerap dibahas dalam literaturliteratur yang menulis tentang partai politik, diantaranya buku yang di tulis Koirudin tahun 2004 dengan judul Partai Politik Dan Agenda Transisi Demokrasi. Dalam bab 3 buku ini penulis memaparkan lima fungsi partai politik, yakni fungsi artikulasi kepentingan, fungsi agregasi kepentingan, fungsi sosialisasi politik, fungsi rekrutmen politik, dan fungsi komunikasi politik. ${ }^{9}$

Sosialisasi politik sebagai suatu cara untuk memperkenalkan nilai-nilai politik, sikap poltiik, dan etika politik memerlukan intervensi partai poltiik sebagai pilar utama demokrasi. Setiap partai politik memiliki target terhadap sosialisasi politik. Memang ada banyak target partai politik melakukan sosialisasi politik, namun yang paling riil dari target partai politik adalah mengkonstruksi kembali perilaku politik masyarakat dalam memilih. Untuk konsteks Indonesia saat ini, perilaku sebagian besar pemilih masih emosional dan tradisional. Kondisi pemilih yang demikian dapat berdampak pada lahirnya

${ }^{8}$ Elly M.Setiadi \& Usman Kollip, Pengantar Sosiologi Politik(Jakarta, Kencana Prenadamdedia Group, 2013), hlm.171

${ }_{9}$ Koirudin, Partai Politik Dan Agenda Transisi Demokrasi (Yogyakarta, Pustaka Pelajar, 2004), hlm. 86. 
lembaga-lembaga dan suprastruktur politik yang juga tradisional. Maka tugas utama partai politik dalam melaksanakan sosialisasi politik adalah memperbaharui konstruksi perilaku memilih dari em osional menjadi rasional. Oleh karena itu, sebaiknya partai politik tidak boleh menjadi agen yang justru memelihara perilaku pemilih emosional atau tradisional. Partai politik bertanggung jawab atas terbangunnya perilaku pemilih rasional.

\section{Pemahaman Sisw a Madrasah Aliah Darul Muhajirin Tentang Pemilu Sebelum Paparan Materi Kepemiluan}

Sebelum penyampaian materi kepemiluan dilakukan pengabdi terlebih dahulu membuat pretest pada peserta untuk mengetahui bagaimana pemahaman Siswa/Siswi MA Darul Muhajirin Praya tentang pemilihan umm (Pemilu). Jumlah peserta dalam pelaksanaan program pengabdian masyarakat ini sebanyak 30 orang. Deskripsi jawaban peserta sebagaimana tabel berikut.

Tabel 2.

Pemahaman Siswa/Siswi MA Darul Muhajirin tentang Pemilu sebelum Paparan Materi

\begin{tabular}{|c|c|c|c|c|}
\hline No & Pertanyaan & Jawaban & Jumlah & $\%$ \\
\hline \multirow[t]{4}{*}{1} & $\begin{array}{l}\text { Apa yang Anda } \\
\text { ketahui te ntang } \\
\text { pemilu? }\end{array}$ & $\begin{array}{l}\text { Kegiatan memilih preside } \mathrm{n}, \\
\text { gubernur dan bupati, serta } \\
\text { DPR,DPRD }\end{array}$ & 15 & 50 \\
\hline & & $\begin{array}{l}\text { Kegiatan kampanye dan bagi- } \\
\text { bagi sembako }\end{array}$ & 10 & 33 \\
\hline & & Perebutan kekuasaan & 5 & 17 \\
\hline & & & $\Sigma$ & 100 \\
\hline \multirow[t]{4}{*}{2} & Apakah Anda & Setuju & 15 & 50 \\
\hline & setuju de ngan & Tidak setuju & 10 & 33 \\
\hline & golput? & Ragu-ragu & 5 & 17 \\
\hline & & & $\Sigma$ & 100 \\
\hline
\end{tabular}

Sumber: Hasil pretest

Tabel 2. memperlihatkan sebelum materi kepemiluan diparapkan oleh narasumber, pemahaman siswa/siswi tentang makna pem ilu masih terbatas. Meskpun demikian 50 \% mereka memahami pemilu sebagai kegiatan memilih presiden, gubernur dan bupati, serta 
DPR,DPRD; 33 \% memahami pemilu sebagai kegiatan kampanye dan bagi-bagi sembako; dan $17 \%$ memahami pemilu sebagai perebutan kekuasaan.

\section{Pemahaman Siswa/Siswi MA Darul Muhajirin Tentang Pemilu Sesudah Paparan Materi Kepemiluan}

Setelah paparan materi kepemiluan diberikan, pengabdi membuat posttest kepada peserta untuk mengetahui bagaimana pemahaman Siswa/Siswi MA Darul Muhajirin Praya tentang pemilu. Stelah diberikan materi kepemiluan, hasilnya sebagaimana tabel 3

Tabel 3

Pemahaman Siswa/Siswi MA Darul Muhajirin Tentang Pemilu

Sesudah Paparan Materi

\begin{tabular}{|c|c|c|c|c|}
\hline No & Perta nyaan & Jawaban & Jumlah & $\%$ \\
\hline \multirow[t]{3}{*}{1} & \multirow[t]{3}{*}{$\begin{array}{l}\text { Apa ya ng Anda } \\
\text { ketahui te ntang } \\
\text { pemilu? }\end{array}$} & $\begin{array}{l}\text { Sarana pelaksanaan kedaulatan } \\
\text { rakyat untuk memilih anggota } \\
\text { DPR, DPD dan DPRD, serta } \\
\text { memilih presiden dan wakil } \\
\text { presiden }\end{array}$ & 25 & 83 \\
\hline & & $\begin{array}{l}\text { Sarana sirkulasi kepemimpinan } \\
\text { politik }\end{array}$ & 6 & 17 \\
\hline & & & $\Sigma$ & 100 \\
\hline \multirow[t]{4}{*}{2} & \multirow{4}{*}{$\begin{array}{l}\text { Apakah } \\
\text { setuju de } \\
\text { golput? }\end{array}$} & Setuju & 5 & \\
\hline & & Tidak setuju & 28 & 93 \\
\hline & & Ragu-ragu & 2 & 7 \\
\hline & & & $\Sigma$ & 100 \\
\hline
\end{tabular}

Sumber: Hasil Postest

Tabel 3. memperlihatkan adanya perubahan pemahaman siswa/siswi tentang pemilu sekaligus perubahan sikap mereka terhadap isu golput setelah selesai pemaparan materi oleh narasumber. Ketika ditanya apa yang anda ketahui tentang pemilu? Sebanyak 83 $\%$ mereka mampu memberikan jawaban dengan sangat baik, hanya $17 \%$ yang memberikan jawaban kurang baik. Sedangkan ketika ditanya apakah anda setuju dengan golput? Sebanyak $93 \%$ menyatakan tidak setuju, dan hanya $7 \%$ yang masih ragu-ragu.

\section{Penutup}


Dari proses penyelenggaraan penganbdian masyarakat di atas, memperlihatkan hasil yang ditunjkkan oleh program pendidikan pemilih sebagai tematik kegiatan ini. Sebelum peyelenggaraan pengabdian masyarakat dilakukan pemahaman siswa/siswi tentang makna pemilu masih sangat terbatas. Sebanyak $50 \%$ mereka memahami pemilu sebagai kegiatan memilih presiden, gubernur dan bupati, serta DPR,DPRD; $33 \%$ memahami pemilu sebagai kegiatan kampanye dan bagi-bagi sembako; dan $17 \%$ memahami pemilu sebagai perebutan kekuasaan. Dan setelah pengabdian masyarakat dilakukan, terjadi perubahan pemahaman siswa/siswi tentang pemilu sekaligus perubahan sikap mereka terhadap isu golput setelah selesai pemaparan materi oleh narasumber. Sebanyak $83 \%$ mereka mampu memberikan jawaban dengan sangat baik, hanya $17 \%$ yang memberikan jawaban kurang baik. Sedangkan sikap mereka tentang golput, sebanyak $93 \%$ menyatakan tidak setuju, dan hanya $7 \%$ yang masih ragu-ragu. Dengan demikian, dapat disimpulkan bahwa pendidikan pemilih efektif sebagai metode terhadap meningkatnya pengetahuan dan keterampilan siswa/siswi tentang kepemiluan serta berpengaruh terhadap sikap politik mereka menolak golput. Dan terbangunnya komitmen mereka berpartisipasi dalam pemilu.

\section{Daftar Pustaka}

Damsar, Prof, Dr.,2010, Pengantar Sosiologi Politik, Edisi Revisi

(Kencana Prenada Media Group, 2010)

Gatra, A.A.Said \& Moh.Dzulkiah Said,2007,Sosiologi Politik Konsep

Dan Dinamika Perkembangan Kajian, Bandung, Pustaka Setia http://kumpulan-berita-unik.blogspot.co.id/2014, dikutp tanggal 25 Februari 2017

Koirudin, 2004, Partai Politik Dan Agenda Transisi Demokrasi,

Yogyakarta, Pustaka Pelajar

Komisi Pemilihan Umum RI, Buku Data dan Infografik Pemilu Anggota

DPR RI dan DPD RI Tahun 2014.

Setiadi, Elly, M. \& Usman Kollip, 2013, Pengantar Sosiologi Politik, Jakarta, Kencana Prenadamdedia Group 
Sunarto, Kumanto, 2004, Pengantar Sosiologi Edisi Revisi, Fakultas Ekonomi Universitas Indonesia

Suryadi, Budi, 2007, Sosiologi Politik; Sejarah, Definisi, dan Perkembangan Konsep Jogjakarta, IRCiSoD 